\title{
memorandum
}

DATE: January 30, 1995

REPLY TO

ATTN OF:

SUBJECT:

TO:

The purpose of this memorandum is to provide Program Offices and Field Organizations with updated guidance on release notification requirements under the Comprehensive Environmental Response, Compensation, and Liability Act (CERCLA) and the Emergency Planning and Community Right-to Know Act (EPCRA). The attached guidance updates and expands upon information provided in earlier guidance published jointly by the Environmental Protection Agency (EPA) and the Department of Energy (DOE) entitled: Guidance for Federal Facilities on Release Notification Requirements under CERCLA and SARA Title III (EPA 9360.7-06; November 1990). ${ }^{1}$

CERCLA establishes a framework for Federal involvement in response to and cleanup of hazardous substance releases. A key provision of CERCLA deals with mandatory notification requirements regarding the release of hazardous substances into the environment. Title III of the Superfund Amendments and Reauthorization Act of 1986 (SARA), known as the Emergency Planning and Community Right-to Know Act (EPCRA), also requires owners/operators of facilities that release designated hazardous substances or extremely hazardous substances to report such releases to state and local authorities. ${ }^{2}$ Significant events have occurred since publication of the joint EPADOE guidance on release notification requirements that affect reporting obligations of DOE facilities. In particular, the enactment of Executive Order 12856 - Federal Compliance with Right-to-Know Laws and Pollution Prevention Requirements, and the decision by the United States Court of Appeals rejecting EPA's interpretation of the term "release into the environment" (see The Fertilizer Institute v. United States Environmental Protection Agency, 935 F.2d 1303, 1309-10 (D.C. Cir. 1991) have had an impact on Federal facilities implementation of release notification requirements, necessitating a guidance update.

In preparing the attached guidance update, the Office of Environmental Policy and Assistance, RCRA/CERCLA Division (EH-413), incorporated the aforementioned changes, documented responses to queries from DOE field elements on release reporting requirements, and incorporated those question and answers (Qs\&As) from the earlier joint guidance that remain germane to DOE reporting obligations under CERCLA and EPCRA. Questions regarding release notification requirements, in general, or the attached guidance, in particular, may be directed to Rich Dailey of my staff at (202) 586-7117.

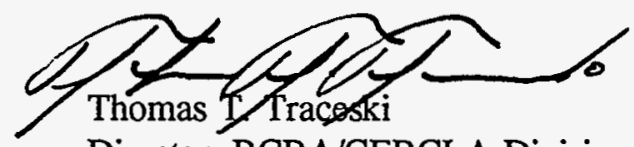

Director, RCRA/CERCLA Division

Office of Environmental Policy and Assistance

Attachment

${ }^{1} \mathrm{EH}-231$ Memorandum dated March 29, 1991, subject: Guidance for Federal Facilities on Release Notification Requirements under CERCLA and SARA Title III

${ }^{2} \mathrm{EH}-231$ Memorandum dated May 24, 1994, subject: Environmental Guidance on Reporting Releases of Hazardous Substances at DOE Facilities (Pub: DOE/EH-0383 "Hazardous Substance Release Reporting under CERCLA, EPCRA §304 \& DOE Emergency Management System/Occurrence Reporting Requirements") 


\section{Program Offices}

Al Knight, CI-20

Dennis Miotla, DP-13

Daniel Rhoades, DP-24

Charles Halsted, DP-27

Donald Knuth, DP-30

Ken Ferlic, DP-31

John Ford, DP-33

John Marchetti, DP-34

OJ. Lawrence, EE-64

Mike Whitaker, EH-6

Pat Worthington, EH-12

Joe Fitzgerald, EH-30

Paul Seligman, EH-40

Rick Jones, EH-41

Jim Disbrow, EI-523

Richard Guimond, EM-2

Jim Werner, EM-4

Don Donaldson, EM-121

Randal Scott, EM-20

Mike Kleinrock, EM-22

Jill Lytle, EM-30

Jim Turi, EM-33

Lee Stevens, EM-331

Mark Frei, EM-34

Kent Hancock, EM-334

Jaseph Coleman, EM-35

Jay Rhoderick, EM-351

John Tseng, EM-36

Jack Baublitz, EM-40

Jim Fiore, EM-42

James Wagoner, EM-421

Richard Nace, EM-422

Kimberly Chaney, EM-423

Bill Wisenbaker, EM-43

Kelvin Kelkenberg, EM-431

Sally Robison, EM-44

Carl Bauer, EM-441

Jane Monhart, EM-442

Anthony Kluk, EM-443

Ralph Lightner, EM-45

David Mathes, EM-451

John Ahlquist, EM-452

Raymond Greenberg, EM-453

Clyde Frank, EM-50

Tom Evans, EM-533

Larry Weiner, EM-60

Kitty Gandee, EM-62

James Farley, ER-8.2

Frederick Koomanoff, ER-10

Albert Evans, ER-13

Sat Goel, ER-14

David Goodwin, ER-20

Omer Goktepe, ER-22

Joseph McGrory, ER-23

Steven Rossi, ER-54

Robert Wood, ER-73

James Carney, ER-912

Craig Zamuda, FE-6

Phoebe Hamill, FE-222

N. L. Johnson, FE-33

R.D. Furiga, FE-40

Hal Delaplane, FE-423

Mark Matarrese, FE-64

Frankin Peters, FM-1

William Dennison, GC-11

Tom Evans, HR-33

Jim Fairobent, IS-60

Janie Benton, NE-33
Raj Sharma, NE-443

Robert Gisch, NE-60

Joanna Stancil, PA-3

David Moses, PO-60

Steve Brocoum, RW-22

Dwight Shelor, RW-30

Gerald Parker, RW-333

A.G. Joseph, LM-1.

John Yates, LM-1

Rodney Adelman, PML [8G-027]

\section{Fleld Omces}

N. S. Dienes, Albuquerque Operations Office P.M. Ramey, Albuquerque Operations Office Rich Sena, Albuquerque Operations Office C. L. Soden, Albuquerque Operations Office Debbie Miller, Albuquerque Operations Office Sally Arnold, Batavia Area Office Mike Butler, Brookhaven Area Office D.J. Cook, Central Training Academy, AL M. Flannigan, Chicago Operations Office Joel Haugen, Chicago Operations Office Jack Craig, Fernald Field Office Jerry Lyle, Idaho Operations Office Gerald C Bowman, Idaho Operations Office Donald MacDonald, Idaho Operations Office Lisa Green, Idaho Operations Office Walt Sato, Idaho Operations Office Peggy Hinman, Idaho Operations Office Bruce Church, Nevada Operations Office Don Elle, Nevada Operations Office Joe Fiore, Nevada Operations Office Steve Mellington, Nevada Operations Office Peter Gross, Oak Ridge Operations Office H. Wayne Hibbitts, Oak Ridge Operations Office Rodney R. Nelson, Oak Ridge Operations Office L.K. Price, Oak Ridge Operations Office Larry Radcliff, Oak Ridge Operations Office Suzy Riddle, Oak Ridge Operations Office Robert Sleeman, Oak Ridge Operations Office Sue Smiley, Ohio Field Office

Don Alexander, Richland Operations Office

J. Bauer, Richland Operations Office Gerald M. Bell, Richland Operations Office Rudy Guercia, Richland Operations Office Bob Holt, Richland Operations Office R.D. Freeberg, Richland Operations Office Frazier Lockhart, Rocky Flats Office David Brockman, Rocky Flats Office Jessie Roberson, Rocky Flats Office David Ruscitto, Rocky Flats Office Mark Silverman, Rocky Flats Office E. Ballard, Oakland Operations Office Jim Davis, Oakland Operations Office Alex Dong, Oakland Operations Office Joe Juetten, Oakland Operations Office Roger Little, Oakland Operations Office Terry Vaeth, Oakland Operations Office Thomas Heenan, Savannah River Operations Office Tom Treger, Savannah River Operations Office A.B.Gould, Savannah River Operations Office Lenard Sjostrom, Savannah Operations Office M.G. O'Rear, Savannah River Operations Office Steve Wright, Savannah River Operations Office R. B. Provencher, West Valley Project Office T.J. Rowland, West Valley Project Office Rob Waldman, Alaska Power Administration Alex Crawley, Bartlesville Project Office Thomas Wesson, Bartlesville Project Office Alexandra Smith, Bonneville Power Administration, AJ
Thru: BPA, RM 8G033

John Ganz, Morgantown Energy Technology Center Joseph Martin, Morgantown Energy Technology Ctr Jim Killen Naval Petroleum Reserves in California

D. Miles, Naval Petroleum Reserves in Wyoming, Utah, \& Colorado, Casper, WY

Melvin Keller, Pittsburgh Energy Technology Center

Earl Shollenberger, Pittsburgh Naval Reactors Office, Thru: NE-60

Andrew Seepo, Schenectady Naval Reactors Office, Thru: NE-60

Jim Lloyd, Southeastern Power Administration

Don Hayes, Southwestern Power Administration

Melissa Smith, Strategic Petroleum Reserve Project Managemen Office

Vicki Ponce, Western Power Administration

Gerald Johnson, Manager, Amarillo Area Office (AAO)

Larry D. Kirkman, Manager, Dayton Area Office (DAO)

Earl Bean, Manager, Kansas City Area Office (KCAO)

Kathleen Carison, Manager, Kirtland Area Office (KAO)

Jerry Bellows, Acting Manager, Los Alamos Area Office (LAAO'

Richard E. Glass, Manager, Pinellas Area Office (PAO)

Milton D. Johnson, Princeton Area Office

James R. Lampley, Manager, Grand Junction Projects Office

Phillip Hill, Livermore Site Office (LSO)

George E. Dials, Waste Isolation Pilot Plant Project Office (WIPP-AL)

Beth Bennington, WIPP Project Office (WIPP-AL)

A. R. Chernoff, Jr., Project Manager, Uranium Mill Tailings

Remedial Action Project Office

Wendy Dixon, Yucca Mountain Project Office

Paul K. Kearns, Manager, NREL, Golden Office

Jeff Baker, NREL, Golden Office

Jim Doskocil, SSCPO

\section{ce: Other Organizations}

National Low-Level Waste Management Program, EG\&G Idaho Hazardous Waste Remedial Action Program, (HAZWRAP)

Remedial Action Program Information Center

Center for Environmental Management Information 


\section{CERCLA $\$ 103$ and EPCRA $\$ 304$ RELEASE NOTIFICATION REQUIREMENTS Update}

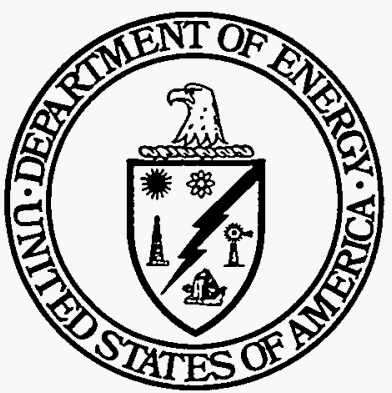

\section{JANUARY 1995}

Prepared by

\section{U.S. DEPARTMENT OF ENERGY}

OFFICE OF ENVIRONMENTAL POLICY \& ASSISTANCE

(formerly the Office of Environmental Guidance)

RCRA/CERCLA DIVISION

(EH-413)

W ashington, D.C.

Technical support by

Pacific North west Laboratories

Richland, WA
E.B. Warhit, Inc.

Burke, VA

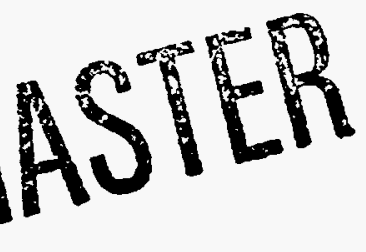




\section{DISCLAIMER}

This report was prepared as an account of work sponsored by an agency of the United States Government. Neither the United States Government nor any agency thereof, nor any of their employees, make any warranty, express or implied, or assumes any legal liability or responsibility for the accuracy, completeness, or usefulness of any information, apparatus, product, or process disclosed, or represents that its use would not infringe privately owned rights. Reference herein to any specific commercial product, process, or service by trade name, trademark, manufacturer, or otherwise does not necessarily constitute or imply its endorsement, recommendation, or favoring by the United States Government or any agency thereof. The views and opinions of authors expressed herein do not necessarily state or reflect those of the United States Government or any agency thereof. 


\section{DISCLAIMER}

Portions of this document may be illegible in electronic image products. Images are produced from the best available original document. 


\section{TABLE OF CONTENTS}

INTRODUCTION .............................. 1

CERCLA Reporting Requirements ..................... 1

EPCRA Reporting Requirements . . . . . . . . . . . . . . . 3

QUESTIONS AND ANSWERS $\ldots \ldots \ldots \ldots \ldots \ldots \ldots \ldots \ldots \ldots \ldots$

WHEN IS A RELEASE REPORTABLE UNDER CERCLA OR EPCRA? . . . . 5

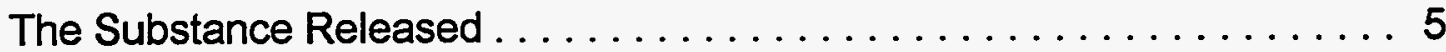

Location of the Release . . . . . . . . . . . . . . . . . . . 6

Environment vs. Open Containment Devices $\ldots \ldots \ldots \ldots \ldots \ldots 6$

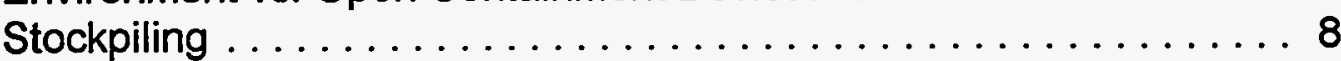

Beyond the Facility Boundary $\ldots \ldots \ldots \ldots \ldots \ldots \ldots \ldots . . \ldots$

HOW SHOULD THE QUANTITY RELEASED BE DETERMINED? . . . . . . . 10

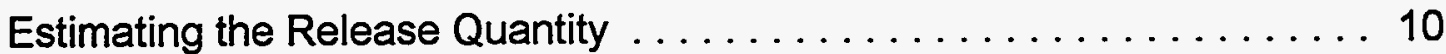

Mixtures .............................. 10

WHO MUST BE NOTIFIED ABOUT A REPORTABLE RELEASE UNDER

CERCLA AND EPCRA, AND WHEN? $\ldots \ldots \ldots \ldots \ldots \ldots \ldots \ldots \ldots 11$

Telephone Calls ............................ 11

Written Follow-up Reports . . . . . . . . . . . . . . . . 12

Any Potentially Affected SERC and LEPC $\ldots \ldots \ldots \ldots \ldots \ldots 13$

WHO MUST REPORT AND WHEN? $\ldots \ldots \ldots \ldots \ldots \ldots \ldots \ldots \ldots \ldots \ldots$

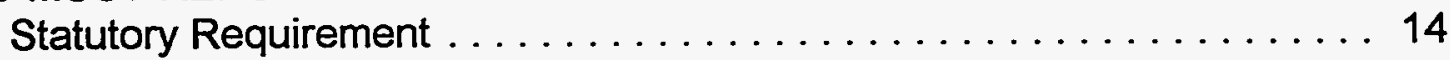

Implications for DOE Facilities $\ldots \ldots \ldots \ldots \ldots \ldots \ldots \ldots \ldots$

WHAT RELEASES ARE EXEMPT FROM CERCLA AND EPCRA? $\ldots \ldots \ldots 16$

Federally Permitted Release Determinations $\ldots \ldots \ldots \ldots \ldots \ldots 18$

HOW SHOULD CONTINUOUS RELEASES BE REPORTED? . . . . . . . 19

Qualifying Releases ....................... 19

Reduced Reporting Requirements .................. 20

RELEASE SCENARIOS $\ldots \ldots \ldots \ldots \ldots \ldots \ldots \ldots \ldots \ldots \ldots \ldots \ldots$

APPENDIX A - LIST OF HAZARDOUS AIR POLLUTANTS . . . . . . . . . 27

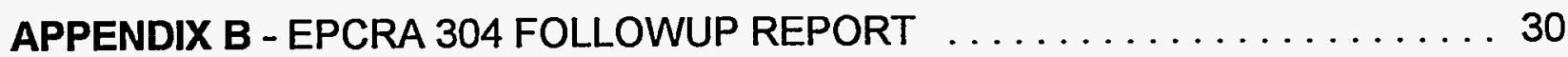




\section{INTRODUCTION}

This guidance document updates and clarifies information provided in an earlier guidance document published by the U.S. Environmental Protection Agency (EPA) entitled Guidance for Federal Facilities on Release Notification Requirements under CERCLA and SARA Title III (EPA 9360.7-06; November 1990). ${ }^{1}$ Since publication of that earlier guidance document, several significant events have occurred that affect the reporting obligations of facilities owned or operated by the Department of Energy (DOE), including the publication of Executive Order 12856 - Federal Compliance with Right-to-Know Laws and Pollution Prevention Requirements - and a rejection by the United States Court of Appeals of EPA's interpretation of the term "release into the environment." (See The Fertilizer Institute $v$. United States Environmental Protection Agency, 935 F.2d 1303, 1309-10 (D.C. Cir. 1991)).

In preparing this guidance document, the Office of Environmental Policy and Assistance, RCRA/CERCLA Division (EH-413), has documented responses to queries from DOE field elements on CERCLA and EPCRA release reporting requirements, as well as incorporated those Questions and Answers from the previous document that remain germane to DOE's reporting obligations under CERCLA and EPCRA.

\section{CERCLA Reporting Requirements}

The Comprehensive Environmental Response, Compensation, and Liability Act of 1980 (CERCLA or Superfund), as amended, creates a broad framework for federal involvement in response to and cleanup of hazardous substance releases. Under CERCLA, EPA has broad statutory authority to undertake or require responsible parties to undertake response actions addressing releases of hazardous substances or pollutants and contaminants. Recognizing that EPA could exercise that authority in many instances only if EPA receives notice of such releases as they occur, Congress enacted section 103(a) of CERCLA, which requires the person in charge of a facility or vessel to notify the National Response Center as soon as the person has knowledge of a release of a hazardous substance at or above the reportable quantity (RQ) assigned to that substance.

The section 103(a) reporting requirements are triggered only when there is a "release," which is defined in section 101(22) of CERCLA as any "spilling, leaking, pumping, pouring, emitting, emptying, discharging, injecting, escaping, leaching, dumping, or disposing into the environment." Thus, when a hazardous substance is spilled, leaked, or discharged, the incident must be reported to the National Response

1 EH-231 Memorandum, dated March 29, 1991, Subject: Guidance for Federal Facilities on Release Notification Requirements under CERCLA and SARA Title III. 
Center if the amount that enters the environment within a 24-hour period equals or exceeds an $R Q$.

"Environment" is defined in section 101(8) of CERCLA as "the navigable waters, the waters of the contiguous zone, and the ocean waters ... of the United States ...," and "any other surface water, ground water, drinking water supply, land surface or subsurface strata, or ambient air..."

\section{Hazardous Substances}

Substances are designated as hazardous substances under CERCLA in a number of ways. CERCLA section 101(14) defines "hazardous substance" to include: (A) any substance designated pursuant to section $311(b)(2)(A)$ of the Federal Water Pollution Control Act (also known as the Clean Water Act or CWA); (B) any element, compound, mixture, solution, or substance designated pursuant to section 102 of CERCLA; (C) any hazardous waste having the characteristics identified under or listed pursuant to section 3001 of the Solid Waste Disposal Act (also known as the Resource Conservation and Recovery Act or RCRA); (D) any toxic pollutant listed under CWA section 307(a); (E) any hazardous air pollutant listed under section 112 of the Clean Air Act; and $(F)$ any imminently hazardous chemical substance or mixture with respect to which the Administrator has taken action pursuant to section 7 of the Toxic Substances Control Act. The list of CERCLA hazardous substances is codified in Table 302.4 in 40 CFR 302.4. ${ }^{2}$

Currently there are nearly 800 specifically designated CERCLA hazardous substances. There are also about 1,500 radionuclides that are CERCLA hazardous substances because radionuclides are listed under section 112 of the Clean Air Act. In addition, thousands of RCRA hazardous wastes that are not specifically listed also are CERCLA hazardous substances. These unlisted RCRA hazardous wastes exhibit the characteristics of ignitability, corrosivity, reactivity, or toxicity.

The CERCLA list of hazardous substances is continually changing as a result of legislative and regulatory initiatives. For example, the 1990 amendments to Clean Air Act section 112 expanded the number of hazardous air pollutants from seven to 190 pollutants. Of these 190 hazardous air pollutants, all but 52 were previously listed as hazardous substances in 40 CFR 302.4 . The remaining 52 substances automatically became CERCLA hazardous substances with the enactment of the Clean Air Act

2 Several hazardous substances added by the CAA amendments will not be on Table 302.4 until later in 1995. A list of those hazardous air pollutants may be found in the appendix to this document. Until adjusted by regulation, the RQ for the substances in the appendix is one pound. 
Amendments. Similarly, whenever a hazardous waste stream is listed under RCRA, that waste stream is also designated as a CERCLA hazardous substance.

CERCLA section 102(b) establishes an RQ of one pound for all hazardous substances, unless a different $R Q$ already has been established by regulation. CERCLA section 102(a) authorizes the EPA Administrator to adjust RQs by regulation.

For CERCLA hazardous substances other than radionuclides, RQs are in units of pounds, and are divided among five RQ categories: 1, 10,100,1000, or 5000 pounds. Each of the 52 newly designated hazardous air pollutants has an $R Q$ of one pound, until EPA adjusts the $R Q$ by regulation. ${ }^{3}$ The adjusted $R Q$ s for radionuclides are in units of curies and range between 0.001 curie and 1000 curies. Unlisted RCRA hazardous wastes that exhibit the characteristics of ignitability, corrosivity, or reactivity, as those terms are defined in 40 CFR 261, have an RQ of 100 pounds. The applicable $\mathrm{RQ}$ for each hazardous substance is listed in Table 302.4 in 40 CFR 302.4.

The $R Q$ acts as a reporting trigger; when an $R Q$ or more of a hazardous substance is released into the environment within a 24-hour period, CERCLA $\$ 103(a)$ requires that the person in charge report the release immediately to the National Response Center.

\section{EPCRA Reporting Requirements}

Section 304 of the Emergency Planning and Community Right-to-Know Act (EPCRA), also known as Title III of the Superfund Amendments and Reauthorization Act (Title III of SARA), requires owners and operators of facilities where hazardous chemicals are produced, used, or stored to report releases of CERCLA hazardous substances or extremely hazardous substances (EHSs) to state and local authorities (i.e., state emergency response commissions (SERCs) and local emergency planning committees (LEPCs)).

EHSs are listed in Appendices A and B of 40 CFR 355. There currently are 360 EHSs; 138 of the EHSs are also CERCLA hazardous substances. Reportable releases of an RQ or more of a substance that is both an EHS and a CERCLA hazardous substance must be reported to the National Response Center, SERC, and LEPC;

3 EPA has published a proposed rule to adjust the RQs for about 50 newly designated hazardous substances. See 58 FR 54836; October 22, 1993. 
similar releases of an EHS that is not a CERCLA hazardous substance must be reported only to state and local officials.

EPCRA $\$ 304$ requires the owner or operator of a facility to immediately report to the SERC and LEPC any release of a CERCLA hazardous substance or an EHS that equals or exceeds an $R Q$ within a 24-hour period, and has the potential to migrate offsite.

When EPCRA was first enacted in 1986, federal facilities were not required to comply with its provisions, although DOE management always encouraged its facilities to comply voluntarily and to work closely with the communities surrounding each site. On August 3, 1993, E. O. 12856, "Federal Compliance with Right-to-Know Laws and Pollution Prevention Requirements," was signed by the President. This Executive Order formally requires all federal facilities to comply with EPCRA and the Pollution Prevention Act. Compliance is no longer voluntary.

The emergency release notification requirements under CERCLA and EPCRA are closely related. For example, both CERCLA and EPCRA rely on RQs as reporting triggers. In addition, reporting exemptions established under CERCLA also apply to EPCRA; EPCRA only requires reports of releases that are reportable under CERCLA or that occur in a manner that would make them reportable under CERCLA. Hence, if a release is exempt from reporting under CERCLA (e.g., the release is not into the environment or the release is federally permitted), it also would be exempt under EPCRA. However, there are some important differences between the exclusions and definitions in CERCLA and EPCRA that affect notification requirements. These differences often cause confusion. This guidance document attempts to clarify these differences and eliminate any confusion to the extent possible.

The following guidance addresses issues related to CERCLA and EPCRA emergency release notification requirements. EPA has not always provided definitive guidance as to how one should determine the applicability of the CERCLA and EPCRA notification provisions. At times, the decision to report, or not to report, releases under CERCLA or EPCRA will come down to a judgment call. EPA does not, and DOE cannot, always provide quantitative measures or formulas that can be used to determine reporting responsibilities. The information presented in this guidance, therefore, should not be considered official EPA policy. $D O E$ believes, however, that if the guidance presented in this document is followed, DOE will have made its best effort to comply fully with both the letter and the intent of the CERCLA and EPCRA emergency release notification provisions. 


\section{QUESTIONS AND ANSWERS}

\section{WHEN IS A RELEASE REPORTABLE UNDER CERCLA OR EPCRA?}

\section{The Substance Released}

CERCLA focuses solely on

releases of hazardous substances.
EPCRA focuses on both hazardous substances and extremely hazardous substances (EHSs).

CERCLA hazardous substances include all substances specifically listed in 40 CFR 302.4, as well as wastes exhibiting characteristics of ignitability, corrosivity, and reactivity (ICR) under RCRA. EPA considers a release of a non-designated substance that exhibits an ICR characteristic to be a release of a CERCLA hazardous substance, if the substance is a waste prior to release, or if the substance is not cleaned up for reuse and thus must be disposed of as a RCRA waste after release. (See $50 \mathrm{FR}$ 13460; April 4, 1985.) In either case, the $R Q$ is 100 pounds.

The release of a non-designated CERCLA hazardous substance that exhibits an ICR characteristic and that is not cleaned up for reuse is considered a release of a CERCLA hazardous substance; its $R Q$ is $100 \mathrm{lbs}$.

On July 14,1991, 19,500 gallons of the herbicide metam sodium was spilled from a derailed tank car into the Sacramento River. Metam sodium is not a listed CERCLA hazardous substance or a listed EHS ${ }^{4}$. Nonetheless, EPA believes that the spill should have been reported to the National Response Center, SERC, and LEPC under the provisions of CERCLA $\$ 103$ and EPCRA $\$ 304$. When the metam sodium spilled from the tank car, it immediately hydrolyzed or decomposed into at least three specifically listed CERCLA hazardous substances. Immediate notification to the National Response Center, SERC, and LEPC is advisable in situations such as the metam sodium spill, because it is EPA's current position that notification is required when a non-CERCLA substance rapidly ${ }^{5}$ degrades into a CERCLA hazardous substance in an

4 EPA published a proposed rule on March 1, 1994, to add metam sodium to Table 302.4 as a CERCLA hazardous substance.

5 To date, EPA has not provided any guidance on the meaning of the word "rapidly." Therefore, best judgment must be used to determine if the chemical transformation occurs fast enough to warrant notification under CERCLA and/or EPCRA. 
amount that equals or exceeds the RQ for the CERCLA substance. It also may be argued that the metam sodium spill came within the definition of a hazardous substance under CERCLA because, when spilled, it exhibited an ICR characteristic that defines a hazardous waste under RCRA, and RCRA hazardous wastes are considered CERCLA hazardous substances. As a RCRA characteristic waste, it had an RQ of 100 pounds. Thus, in these two ways, it may be argued that the CERCLA and EPCRA emergency release notification requirements became applicable to this spill situation.

A release of a non-CERCLA substance may be reportable under CERCLA and EPCRA if the released substance rapidly forms a CERCLA hazardous substance. The applicable $R Q$ is the $R Q$ for the newly formed substance.

\section{Location of the Release}

CERCLA requires reports when an $R Q$ or more of a hazardous substance enters the environment within a 24-hour period.
EPCRA requires reports when an $\mathrm{RQ}$ or more of a hazardous substance or EHS enters the environment within a 24-hour period, and the "release does not result in exposure to persons solely within the boundaries of the facility."

\section{Environment vs. Open Containment Devices}

CERCLA $\S 101(8)$ defines "environment" to mean "(A) the navigable waters, the waters of the contiguous zone, and the ocean waters ... of the United States ..., and (B) any other surface water, ground water, drinking water supply, land surface or subsurface strata, or ambient air..."

Confusion arises because some land surfaces may actually be used as containment devices (e.g., clay-lined or synthetically lined disposal facilities, a concrete pad or clay dike surrounding a tank). Discharges into containment devices are NOT releases into the environment. (See The Fertilizer Institute v. United States Environmental Protection Agency, 935 F.2d 1303, 1309-10 (D.C. Cir. 1991)). In the Fertilizer Institute case, the court ruled that a release of a non-volatile substance into an open containment device may be a threatened release but was not an actual release, and CERCLA \$103 requires reports be made only for actual releases into the environment. 
EPA has not yet clarified when structures are open containment devices and when they are part of the environment. Therefore, until EPA provides more definitive guidance, the Department provides the following guidance:

- If a structure is properly designed, constructed, and maintained to contain a hazardous substance, then a release into or onto that structure is NOT a release into the environment and is not reportable under CERCLA or EPCRA, so long as the hazardous substance does not volatilize into the ambient air or otherwise enter the environment.

- $\quad$ Although discharge of hazardous substances into such containment structures are not releases into the environment and, therefore, are not subject to CERCLA notification provisions, they may be considered threatened releases into the environment, and therefore are subject to CERCLA response and liability provisions (i.e., pursuant to CERCLA $\$ \$ 104$ \& 107, EPA may authorize a CERCLA response action and hold DOE liable for the response costs).

Examples of releases into open containment devises that DOE believes would not be subject to CERCLA $\$ 103$ or EPCRA $\$ 304$ reporting requirements include:

- A release of a non-volatile substance onto a concrete pad with provisions to catch any runoff;

- A release into a clay-lined or synthetically lined disposal facility that is properly designed, constructed, and maintained to contain the discharged substance;

- A release into a properly designed, constructed, and maintained clay ditch or dike;

- A release of a non-volatile substance into an open tank; and

- A release of a substance into a pipe or sewer that leads to a holding tank.

A release into a structure that is properly designed, constructed, and maintained to contain a hazardous substance, and in fact does contain the released substance, is not subject to CERCLA \$103 or EPCRA §304 reporting requirements. 
- If a reasonable person can conclude that a release of a hazardous substance into or onto a structure must eventually enter the environment, then a release into that structure should be considered a release into the environment and would be subject to CERCLA and EPCRA notification requirements.

Examples of releases into the environment that DOE believes would be subject to CERCLA $\$ 103$ or EPCRA $\$ 304$ reporting include:

- A release of a substance into a storm drain or sewer that eventually leads to a river;

- A release of a substance into an open containment device that fails to contain an RQ or more of the substance; and

- A release of a substance onto a roadway, parking lot, or tarmac.

\section{Stockpiling}

The outdoor stockpiling of an RQ or more of a hazardous substance, including radionuclides, may be a release to the environment that must be reported to the National Response Center. The determinative factor is whether the stockpiling represents placement of hazardous substances into the environment (e.g., the soil), or whether the stockpiling represents placement of hazardous substances into or onto an open containment structure. If the stockpiling is onto a containment structure (e.g., thick concrete pad with provisions to catch runoff and prevent seepage to the soil below the pad) and no subsequent release of an RQ or more of a hazardous substance escapes from the pile into the environment during a 24-hour period, then the stockpiling of the hazardous substance may NOT be a release into the environment reportable under CERCLA. ${ }^{6}$ Instead, the stockpiling would represent a release into an open containment structure. However, if an RQ or more of a hazardous substance is released from the stockpile to the air, soil, or other environmental medium within a 24hour period, it must be reported under CERCLA. ${ }^{7}$

6 Even routine stockpiling activities that are into the environment may not need to be repeatedly reported under CERCLA $\$ 103(a)$; such releases may be subject to the reduced reporting provisions available for continuous releases under CERCLA $\$ 103(f)(2)$. See 40 CFR 302.8 and available guidance documents.

7 EPA published a proposed rule addressing administrative reporting exemptions for certain radionuclide releases that occur during stockpiling (57 FR 56726; November 30, 1992). The final rule has not been promulgated to date. 


\section{Beyond the Facility Boundary}

EPCRA $\S 304$ requires the owner or operator of a facility to report any release into the environment that equals or exceeds an RQ within a 24-hour period, so long as the release does not result in exposure to persons solely within the boundaries of the facility. This phrase has been interpreted broadly by EPA to mean that releases of an $\mathrm{RQ}$ or more should be reported if any amount of the release has any potential to migrate offsite. Notification ensures that authorities are notified of every potentially harmful release, leaving to the authorities the decision of what response, if any, is appropriate.

Exposure to persons offsite is not a prerequisite for triggering the notification requirements of EPCRA $\$ 304$.

EPA defines "potential" very broadly. For example:

- An air release of any quantity has the potential to migrate offsite;

- A release to soil that can contaminate worker's shoes or clothes has the potential to migrate offsite;

- A release to any waterbody has the potential to migrate offsite.

Any release into the environment that equals or exceeds an $R Q$ within a 24-hour period, and that has the potential (in the broadest sense) to migrate offsite, should be reported to the SERC and LEPC, as well as to the National Response Center.

The burden of proof is on the facility to show that any release into the environment of an RQ or more of a hazardous substance or EHS, that is not reported, has NO POTENTIAL for offsite migration. Therefore, if the decision is made not to report the release to the SERC or LEPC because there is NO POTENTIAL that the release could ever leave the site, be sure to document the facts supporting that finding. In doing so, however, it may not be prudent to spend time modeling and measuring releases to determine the potential for offsite migration. If it is not "obvious" that there is no potential for the release to go offsite, then the best policy would be to notify any potentially affected SERC and LEPC about the release. 


\section{HOW SHOULD THE QUANTITY RELEASED BE DETERMINED?}

\section{Estimating the Release Quantity}

Estimates of the quantity released must have a sound, technical basis, and should rely on available data.
Neither CERCLA nor EPCRA requires monitoring.

DOE has developed a computer software program called "RQ Calculator" that may be used to facilitate comparisons of the quantity released with the applicable RQs. The RQ Calculator translates different units of measurement into pounds - the RQ unit. $^{8}$

\section{Mixtures}

RQs are not additive for most $\mathrm{RQs}$ are additive for radionuclides. hazardous substances.

The mixture rules are identical under CERCLA and EPCRA. A release of a mixture of nonradioactive hazardous substances must be reported to the National Response Center if any constituent of the mixture is released in an amount that equals or exceeds its $R Q$. If the concentrations of the hazardous substance constituents in the mixture are known, then each constituent should be evaluated separately to determine if an $R Q$ or more of that constituent was released to the environment within a 24-hour period. If the concentrations of all the hazardous substance constituents in the mixture are NOT known, then the release must be reported if the quantity of the MIXTURE released within a 24-hour period equals or exceeds the lowest $R Q$ of any of its constituents.

Quantities released of different radionuclides in a mixture ARE additive under the mixture rule for radionuclides. If the identity and quantity of each radionuclide component in a mixture are known, the decision whether to report the release must be made in the following manner: for each radionuclide in the mixture, determine the ratio between the quantity released and the $R Q$ for the radionuclide. If the sum of the fractions is less than one, the release need not be reported. If the sum of the fractions is equal to or greater than one, the release must be reported to the National Response Center.

8 For more information on the RQ Calculator or to obtain a copy of the software, contact the Office of Environmental Policy and Assistance, RCRA/CERCLA Division at 202-586-6374. 


\section{MIXTURE RULE FOR RADIONUCLIDES}

$R E P O R T$ if $Q_{1} / R Q_{1}+Q_{2} / R Q_{2}+\ldots+Q_{n} / R Q_{n} \geq 1$

\section{MIXTURE RULE FOR OTHER HAZARDOUS SUBSTANCES AND EHSS}

$$
R E P O R T \text { if } Q_{1} \geq R Q_{1} \text { or } Q_{2} \geq R Q_{2} \text { or } Q_{n} \geq R Q_{n}
$$

\section{WHO MUST BE NOTIFIED ABOUT A REPORTABLE RELEASE UNDER CERCLA AND EPCRA, AND WHEN?}

\section{Telephone Calls}

The National Response Center must be notified under CERCLA as soon as the person in charge has knowledge.
SERCs and LEPCs likely to be affected by the release must also be notified immediately under EPCRA.

There may be more than one SERC and LEPC potentially affected by a release. It is not always clear where the jurisdiction of one LEPC begins and another LEPC's jurisdiction ends. Do NOT wait for a release to occur to first call the SERCs and LEPCs in your area. Make contact with them prior to a release and ensure that the correct telephone numbers are posted at the appropriate points within your site.

Telephone reports to the National Response Center, SERC, and LEPC should be made as soon as possible after determining that the release is subject to CERCLA and EPCRA emergency release notification provisions.

When reporting a release to the National Response Center, the following information should be provided:

- Name, address, and telephone number of the person reporting the release; 
- Name, address, and telephone number of the person in charge (if different);

- Specific location of the incident;

- Date and time the incident occurred or was discovered;

- Name of the material released;

- Source of the release;

- Cause of the release;

- Total quantity discharged;

- Environmental medium into which the substance was discharged;

- Amount spilled into water;

- Weather conditions;

- Name of carrier or vessel, railcar/truck number, or other identifying information

- Number and type of injuries or fatalities;

- Whether an evacuation has occurred;

- Estimation of the dollar amount of property damage;

- Description of current and future clean-up actions; and

- Identity of other agencies notified or about to be notified about the release.

In addition to notifying outside authorities, the following internal DOE notifications and actions should occur pursuant to DOE Order 5000.3B:

- Facility staff and operators should notify the Facility Manager;

- $\quad$ Appropriate immediate response to the release should begin; and

- $\quad$ The Facility Manager should notify the DOE Facility Representative and the HQ Emergency Operations Center (EOC).

\section{Written Follow-up Reports}

No written follow-up report is required under CERCLA.
EPCRA requires that a written report be sent to the SERC and LEPC at the earliest practicable moment.

The written report required under EPCRA must include information on:

- Actions taken to respond to and contain the release;

- Any known or anticipated health risks associated with the release; and 
- Advice regarding medical attention necessary for any exposed individuals.

Appendix $B$ to this report reprints a copy of an EPCRA 304 written followup report form developed by the Bureau of National Affairs. DOE Order 5000.3B, Occurrence Reporting and Processing of Operations Information, also requires the Facility Manager to submit a written Occurrence Report within 10 working days of the event.

\section{Any Potentially Affected SERC and LEPC}

When a release of a hazardous substance or EHS occurs and the community becomes aware and concerned, the LEPCs and other emergency responders may be the first organizations that are called by concerned citizens. It is very important for the LEPC to be able to provide information to citizens so that proper precautions and responses can be taken to address any serious hazards, and so that panicked responses can be avoided whenever possible.

DOE facilities should make a concerted effort to develop a rapport with neighboring SERCs and LEPCs so that releases at or above an RQ can be reported without hesitation. Not all releases that are reported, and that should be reported, will cause serious injuries or damage; however, when a community has no information, there may be a tendency to believe the worst. Therefore, if there is a potential for a release to go offsite and for the community to become aware of the release, that release should be reported to the potentially affected SERC and LEPC.

The effects do not have to be felt immediately for the community to become concerned about the release. A release of an RQ should be reported to the SERC and LEPC if there is any potential for injuries from the release (whether those injuries are immediate or latent), or if the quantities that go offsite are measurable. For any release of a hazardous substance or EHS that equals or exceeds an RQ, where there is some likelihood that the LEPC will receive inquiries from the public about the release, the LEPC should be notified about the release by the DOE facility and provided with information about the potential hazards and suggested responses, if any.

LEPCs or SERCs adjacent to those areas through which a release plume passes also should be notified of the release if there is a potential to impact traffic and routine emergency (fire, police, ambulance) responses in those adjacent areas. Obviously, if streets are cordoned off and traffic is rerouted, citizens will become aware that something has happened at the site. To avoid overreaction, it is important to notify the LEPC so that appropriate responses can be taken and citizens can be reassured that they are in no danger. 
Reasonable judgment must ultimately be exercised in determining which SERCs and LEPCs should be notified about a release.

\section{WHO MUST REPORT AND WHEN?}

\section{Statutory Requirement}

CERCLA requires the person in charge of a facility or vessel to report the release to the National Response Center, as soon as he or she has knowledge of the release.
EPCRA requires the owner or operator of a facility to report the release immediately to any SERCs and LEPCs in areas potentially affected by the release.

DOE Orders 5000.3B, 5500.1B, and 5500.2B require the facility manager to promptly report releases of hazardous substances that are categorized as reportable occurrences to DOE and all applicable federal, state, local, and tribal authorities. The facility manager at DOE-owned, contractor-operated (GOCO) facilities will be a contractor. Therefore, in accordance with a policy memorandum issued by the Under Secretary, the contractor managing the facility from which a hazardous substance or EHS has been released will be responsible for complying with the CERCLA and EPCRA reporting requirements unless DOE has formally reclaimed that responsibility. ${ }^{9}$

\section{NATIONAL RESPONSE CENTER}

800-424-8802

202-267-2675 (Washington DC)

9 At Power Administrations, which are owned and operated by DOE employees, the facility manager will be a DOE employee. Thus, releases from Power Administrations will be reported by DOE employees. 


\section{Implications for DOE Facilities}

DOE Order 5000.3B establishes a system for reporting operations information within the DOE complex, and processing that information to ensure appropriate corrective action. Order 5000.3B establishes reporting requirements based on the severity of the event or condition; the more severe or risky the situation, the faster the notifications must be made and the more personnel that must be notified.

Under DOE Order 5000.3B, each DOE facility must develop site/facility-specific documentation of Reportable Occurrences applicable to its operations, and written procedures approved by the Program Secretarial Officer. The written procedures must specify a system for ensuring proper categorization of conditions or events; determining appropriate corrective action; and ensuring that such action is effectively taken. The written procedures must delineate the roles and responsibilities of the contractor, DOE Field Organization, HQ Program Office, and HQ Emergency Operations Center (EOC).

Persons responsible for reporting releases of hazardous substances and EHSs to federal, state, and local authorities must be specified in each facility's written response procedures. For DOE facilities, the responsible reporting official will be the facility manager; at GOCO facilities, this person generally will be a senior contractor employee.

Attachment I to DOE Order 5000.3B, CATEGORIZATION OF REPORTABLE OCCURRENCES, provides examples of conditions and events that would constitute different categories of Reportable Occurrences. Categorization of Occurrences must be made as soon as practical, and in all cases within 2 hours of identification.

EMERGENCY is the highest (i.e., most serious) category of Occurrences. Emergencies include any incident that results in or could result in significant offsite consequences.

- Examples of Emergencies include the release of a hazardous substance at levels exceeding 5 times the RQ, and an offsite transportation event causing the release of an $R Q$ of a hazardous substance.

UNUSUAL OCCURRENCES pose significant internal or external threats to safety, environment, health protection, or the ability of a facility to operate. 
- Examples of unusual occurrences include any reportable release of a hazardous substance that exceeds an $R Q$, and any release of 100 gallons or more of oil.

OFF-NORMAL OCCURRENCES include releases that are internal or external threats to safety, security, environmental or health protection, or the ability of a facility to operate.

- Examples of off-normal occurrences include releases of a CERCLA hazardous substance below the $R Q$ but more than one-half an $R Q$; releases of hazardous material below regulatory limits that require non-routine written reports to state and local agencies; and any release of oil less than 100 gallons but greater than 10 gallons.

\section{WHAT RELEASES ARE EXEMPT FROM CERCLA AND EPCRA REPORTING?}

CERCLA §101(22) specifically excludes from the definition of release:

- Emissions from the engine exhaust of a motor vehicle, rolling stock, aircraft, vessel, or pipeline pumping station;

- Releases of source, byproduct, or special nuclear material from a nuclear incident subject to the financial protection provisions of section 170 of the Atomic Energy Act ${ }^{10}$;

- Normal application of fertilizer.

CERCLA §103(a) and EPCRA §304 exclude "federally permitted" releases from the release notification provisions of CERCLA and EPCRA, respectively.

Federally permitted releases are defined in CERCLA §101(10):

- CERCLA $\$ 101(10)(A),(B),(C)$ : Discharges addressed in a National Pollutant Discharge Elimination System (NPDES) permit, permit application, or permit administrative record;

- CERCLA $\$ 101(10)(D):$ Discharges in compliance with a legally enforceable permit for dredged or fill materials under section 404 of the Clean Water Act;

- CERCLA $\$ 101(10)(E)$ : Releases in compliance with a legally enforceable RCRA hazardous waste management facility final permit;

10 Nuclear reactors are the primary type of facility subject to section 170 of the Atomic Energy Act. 
- CERCLA §101(10)(F): Releases in compliance with a legally enforceable permit under the Marine Protection, Research, and Sanctuaries Act;

- CERCLA \$101(10)(G): Any injections of fluids authorized under federally approved underground injection control programs, including federally authorized state programs, pursuant to Part $\mathrm{C}$ of the Safe Drinking Water Act;

- CERCLA \$101(10)(H): Any air emissions subject to permit or control regulations under certain provisions of the Clean Air Act;

- CERCLA \$101(10)(l): Certain well injections of fluids or other materials authorized by state law;

- CERCLA $\$ 101(10)(\mathrm{J})$ : Releases of pollutants to publicly owned treatment works (POTWs) if in compliance with certain pretreatment requirements; and

- CERCLA \$101(10)(K): Releases of source, byproduct, and special nuclear material in compliance with a legally enforceable license, permit, regulation, or order issued pursuant to the Atomic Energy Act.

CERCLA §103 also exempts from CERCLA (and EPCRA) reporting:

- The application of a pesticide product registered under the Federal Insecticide, Fungicide, and Rodenticide Act (FIFRA); and

- The release of a substance that is required to be reported under RCRA Subtitle $C$ and that has been reported to the National Response Center.

CERCLA $§ 101(9)$ exempts from the definition of facility:

- Consumer products in consumer use. ${ }^{11}$

The following radionuclide releases are presently exempt by regulation ( 40 CFR $\S 302.6$ and 40 CFR $\S 355.40$ ):

- Naturally occurring radionuclide releases from large, generally undisturbed land holdings, such as golf courses and parks;

11 Automobiles and trucks are not considered consumer products for purposes of this exemption, even if they are in private use, because they are excluded from the definition of consumer product used by the Consumer Product Safety Commission, and EPA adopted by reference, in 40 CFR $\$ 302.3$, the Commissions' definition of consumer product. 
- Naturally occurring radionuclide releases resulting from the disturbance of large land areas for purposes other than mining, such as farming or building construction; and

- Dumping of coal and coal ash, as well as radionuclide releases to all media from coal and coal ash piles, at utility and industrial facilities with coal-fired boilers.

In addition, in the preamble to the April 4, 1985 final rule (50 FR 13462), EPA stated that, "Where the disposal of wastes into permitted or interim status facilities is properly documented through the RCRA manifest system and RCRA regulations are followed, notification under CERCLA does not provide a significant additional benefit, so long as the facility is in substantial compliance with all applicable regulations and permit conditions."

Proper disposal of hazardous substances at a RCRA-regulated facility is not subject to CERCLA \$103 notification provisions.

\section{Federally Permitted Release Determinations}

Federally permitted releases are exempt from the CERCLA and EPCRA emergency release notification requirements, and the liability provisions of CERCLA \$107. EPA has not yet clarified the federally permitted release definitions in CERCLA $\$ 101(10)$; therefore, determinations of whether releases are federally permitted must rely on the statutory language. Until EPA provides more definitive guidance, the Department provides the following guidance:

- If a radionuclide release occurs as part of normal operations and is within the limits specified in DOE Orders, then the release may be assumed to be federally permitted.

- If a hazardous substance release to air occurs as part of normal operations and is within the limits specified in a NESHAP permit, then the release may be assumed to be federally permitted.

- If a hazardous substance release to water occurs as part of normal operations and is within the limits specified in an NPDES permit, then the release may be assumed to be federally permitted. 
If you believe that a particular release would be covered by the federally permitted release exemption but are unsure, clarify the applicability with the cognizant state or EPA regional office. However, remember:

ANY RELEASE THAT OCCURS THAT IS NOT PART OF NORMAL OPERATIONS WOULD NOT BE CONSIDERED A FEDERALLY PERMITTED RELEASE.

\section{HOW SHOULD CONTINUOUS RELEASES BE REPORTED?}

CERCLA $\S 103(f)(2)$, and EPA regulations at 40 CFR 302.8 and 40 CFR 355.40 , provide for reduced reporting of releases of hazardous substances and EHSs that equal or exceed an RQ within a 24-hour period on a routine or predictable basis, so long as the release occurs in a continuous and stable manner and is part of normal operations or treatment systems.

\section{Qualifying Releases}

Continuous is defined in $40 \mathrm{CFR}$ 302.8 to be without interruption or abatement, or routine, anticipated, intermittent, and incidental to normal operations or treatment processes.
Stable in quantity and rate is defined in 40 CFR 302.8 to mean predictable and regular in the amount and rate of emission.

Examples of reportable releases under CERCLA and EPCRA that may be reported as Continuous Releases include:

- Predictable releases that occur during an approved corrective action or remediation;

- Spills of ethylene glycol that occur on a routine basis from service vehicles at a DOE site;

- Routine releases that occur during maintenance or filling of tanks; and

- Predictable seepage, leaching, or evaporation from a collection pond. 


\section{Reduced Reporting Requirements}

To report a continuous release of a CERCLA hazardous substance that equals or exceeds an RQ within a 24-hour period:

- Make an initial telephone call to the National Response Center, SERC, and LEPC alerting them to the fact that you are reporting a continuous release;

- Submit a written report to the EPA Region, SERC, and LEPC within 30 days of the initial telephone call;

- Submit a written follow-up report one year later to the EPA Region; and

- Make immediate telephone reports to the National Response Center, SERC, and LEPC of statistically significant increases in the release.

To report a continuous release of an EHS that is not a CERCLA hazardous substance:

- Make an initial telephone call to the SERC and LEPC;

- Submit a written report to the SERC and LEPC within 30 days of the initial telephone call; and

- Make immediate telephone reports to the SERC and LEPC of statistically significant increases in the release.

In the written report, information must be provided about the source, composition, and amount of the release. Specifically, the Normal Range of the release must be identified. Any release that exceeds the normal range is defined to be a Statistically Significant Increase (SSI) in the release. These SSI excursions must be reported immediately by telephone to the National Response Center, SERC, and LEPC, as if they were episodic release events.

The continuous release reporting regulation can provide significant reporting relief for routine releases that are not covered by a federal permit. An information packet is available from the EPA Region or EPA HQ, Emergency Response Division, that provides guidance on how to successfully report continuous releases under CERCLA and EPCRA. 


\section{RELEASE SCENARIOS}

1. Must only accidental events be reported, or are there some planned and approved release events that must also be reported under CERCLA and EPCRA?

Any release that equals or exceeds an $R Q$ in a 24-hour period is potentially reportable, unless it is specifically exempt from the CERCLA or EPCRA notification requirements. Some planned and approved releases are exempt from CERCLA $\S 103$ and EPCRA $\S 304$ reporting. For example, federally permitted releases are exempt from reporting, as are releases that result from the proper application of pesticides. However, federally permitted releases encompass only those releases specified in CERCLA \$101(10). Some federally approved releases may not be "federally permitted" and, thus, may be subject to CERCLA and EPCRA notification requirements. For example, a release that occurs during an approved corrective action or pursuant to a signed Record of Decision (ROD) may be a reportable release under CERCLA or EPCRA. Such releases, however, may qualify as "continuous" releases and thus may be subject to reduced reporting provisions.

A signed ROD is NOT equivalent to a federal or state permit; releases that occur as a result of an EPA or state-approved cleanup action may be reportable under CERCLA and EPCRA.

2. Should a release be reported under CERCLA or EPCRA if you are uncertain as to whether an $R Q$ or more was released to the environment?

CERCLA §103(a) requires that reports be made as soon as the person in charge has knowledge of a reportable release. Monitoring of releases is not required under CERCLA or EPCRA, so it is likely that precise estimates of the quantity released may not be available during a spill event. In lieu of monitoring data, estimates of the quantity released should be based on sound, technical judgment. The decision to notify outside authorities should be based on those sound estimates. 
In the event of a reportable release, the Facility Manager should first notify the $D O E$ Facility Representative and the EOC. Notification of the National Response Center, SERC, and LEPC should occur as soon thereafter as possible.

3. Since current theories of carcinogenesis operate on the "no threshold theory," would the presence of an extremely low concentration of a carcinogen constitute an "effect" (i.e., is there a de minimis concentration level below which no report is required under EPCRA)?

EPA will not define a de minimis concentration level below which notification under EPCRA $\S 304$ would not apply. Instead, EPA advises that common sense be used when reporting releases of hazardous substances and EHSs to neighboring SERCs and LEPCs. In addition, they recommend that DOE Facility Managers and staff work closely with neighboring LEPCs to better define the types of releases that should be reported. Many LEPCs own copies of CAMEO TM, Computer-Aided Management of Emergency Operations, a software program that uses the ALOHA ${ }^{\mathrm{TM}}$, Areal Locations of Hazardous Atmospheres, air dispersion model to predict, based on conservative assumptions, the effects of an air release. The LEPCs also have copies of the "Technical Guide for Planning Hazard Analyses." Facility Managers can use the Technical Guide or the ALOHA ${ }^{\mathrm{TM}}$ model, or both, to better understand the types of releases that are likely to be of concern to the neighboring LEPCs.

The burden of proof is on the facility to show that any release into the environment of an RQ or more of a hazardous substance or EHS, that is not reported to the SERC and LEPC, results in exposure to persons solely within the boundaries of the facility.

4. How does the definition of "affected" apply to releases of hazardous substances that pose chronic, rather than acute health effects?

Section 304(a) of EPCRA requires that any release of a hazardous substance or EHS that equals or exceeds an RQ must be reported immediately to any potentially affected SERC and LEPC, so long as the release does not "result in exposure to persons solely within the boundaries of the facility." EPA clarified in 
response to public comment on the regulations implementing EPCRA $\$ 304$, that releases need not result in actual exposure to persons offsite in order to be subject to the release reporting requirements. (See 52 FR 13381, 13383; April 22, 1987.) Notice under EPCRA does not depend upon the possibility of harm from a release, whether that release is a carcinogen or a substance that poses systemic, chronic, or acute health risks. Notice is required for any release into the environment that equals or exceeds an $R Q$ within a 24-hour period, and is encouraged for a release that has the potential to migrate beyond the site boundary. Notification serves the purpose of providing a mechanism whereby authorities become aware of every potentially harmful release, leaving to the authorities the decision as to what response, if any, is appropriate. ${ }^{12}$

Exposure to persons offsite is not a prerequisite for triggering the notification requirements of EPCRA $\$ 304$.

\section{How many adjacent and neighboring SERCs and LEPCs must be notified about the release?}

The purpose of EPCRA $\S \S 302,303$, and 304 , and their implementing regulations, is to promote a partnership between the facility and the LEPC, with both entities working closely to ensure rapid and effective responses to releases of hazardous substances. When a release of a hazardous substance or EHS occurs and the community becomes aware and concerned, the LEPCs and other emergency responders may be the first organizations that are called by concerned citizens. For any release of a hazardous substance or EHS that equals or exceeds an RQ, where there is some likelihood that the LEPC will receive inquiries from the public about the release, the LEPC should be notified about the release by the DOE facility and provided with information about the potential hazards and suggested responses, if any. It is very important for the LEPC to be able to provide information to citizens so that proper precautions and responses can be taken to address any serious hazards, and so that panicked responses can be avoided whenever possible.

12 EPA Brief in Response to Genicom Corporation's Notice of Appeal, EPCRA Appeal No. 92-2, Genicom Corporation v. U.S. EPA. 
6. Does the impact to traffic and deployment of routine emergency (fire, police, ambulance) responders in LEPCs or SERCs adjacent to those areas through which a release plume passes constitute an "affect," thus requiring notification to those LEPCs and SERCs that are not actually touched by the release plume?

NO, there is no legal requirement to report releases to areas not potentially affected by the plume or contamination. However, DOE facility managers are encouraged to notify LEPCs and SERCs in areas adjacent to those areas through which a release plume passes, if there is a potential to impact traffic and routine emergency (fire, police, ambulance) responses in those adjacent areas.

Obviously, if streets are cordoned off and traffic is rerouted, citizens will become aware that something has happened at the site. To avoid overreaction, it is important to notify the LEPC so that appropriate responses can be taken and citizens can be reassured that they are in no danger.

7. Is a release reportable under CERCLA $\$ 103$ or EPCRA $\S 304$ if an RQ of a hazardous substance is discharged within a 24-hour period, but something less than an RQ enters the environment?

NO. CERCLA and EPCRA require only that releases into the environment of an $\mathrm{RQ}$ or more be reported. For example, let's assume a spill occurs inside a building and most of the spill is cleaned up. During the cleanup operation, however, some amount less than an RQ of the substance volatilizes and escapes through a window or is discharged down a drain. Such a release event would not be reportable under CERCLA or EPCRA because less than an RQ was released to the environment.

8. Is a release reportable under CERCLA or EPCRA if an RQ of a hazardous substance spills onto soil, but you are immediately able to recover (i.e., cleanup) most of the spill and the residual in the soil is less than an RQ?

YES. An RQ or more was released to the environment in this situation, thus triggering the CERCLA (and perhaps EPCRA) reporting requirements. Proper and timely response measures should always be taken in the event of a release; however, those measures do not affect your responsibility to report the release under CERCLA or EPCRA.

9. Is a transfer of hazardous substances/waste to a holding pad a reportable release under CERCLA or EPCRA?

PROBABLY NOT. If the holding pad is properly designed, constructed, and maintained to contain the hazardous material, then the pad may be considered an 
open containment device and the transfer would not represent a release into the environment.

10. Given the all-encompassing definition of facility under EPCRA, must releases be aggregated across different buildings to determine if an $R Q$ is released into the environment?

YES. CERCLA §103(a) requires that any release from a facility into the environment that equals or exceeds an $R Q$ within a 24-hour period must be reported to the National Response Center. CERCLA $\$ 101(9)$ defines facility as "any building, structure, installation, equipment, pipe or pipeline, well, pit, pond, lagoon, impoundment, ditch, landfill, storage container, motor vehicle, rolling stock, and aircraft, or any site or area where a hazardous substance has been deposited, stored, disposed of or placed, or otherwise come to be located". EPCRA $\$ 304$ defines facility as "all buildings, equipment, structures, and other stationary items which are located on a single site or on contiguous or adjacent sites and which are owned or operated by the same person..."

EPA has determined that releases of the same hazardous substance or EHS that occur from separate buildings or locations at a DOE facility must be aggregated; if the aggregate quantity released within a 24-hour period equals or exceeds an $R Q$, those releases must be reported to any SERC and LEPC potentially affected by the releases. Releases from different buildings or structures do not need to be aggregated under CERCLA §103; therefore, so long as the release from any one structure does not equal or exceed an RQ within a 24-hour period, the National Response Center need not be notified of the release.

11. If a hazardous substance is released from different buildings or structures at a DOE facility within a 24-hour time period, and each release incident equals or exceeds an RQ, does each release need to be reported separately to the National Response Center, SERC, and LEPC?

NO. Multiple releases of an RQ or more from different facilities may be reported in one phone call to the National Response Center, SERC, and LEPC; multiple phone calls are not required.

12. Is disposal and abandonment of wastes in drums or other containment considered to be releases if the material stays in the drum?

YES. The Superfund Amendments and Reauthorization Act of 1986 expanded the definition of "release" to include the "abandonment or discarding of barrels, containers, and other closed receptacles containing any hazardous substance or pollutant or contaminant." Therefore, disposal of wastes in drums or other closed 
containers is a release under CERCLA. However, the proper disposal of such drums or containers at a RCRA-regulated facility is exempt from the CERCLA $\$ 103$ reporting requirements. (See 50 FR 13460; April 4, 1985.)

13. Is non-episodic migration of contaminants from waste sites into surrounding environmental media subject to CERCLA $\$ 103$ or EPCRA §304 reporting requirements?

YES. A waste site is considered a facility under CERCLA; therefore, a release from a waste site into surrounding environmental media would be a release from a facility into the environment. Such releases, however, would not have to be reported on a per-occurrence basis; rather, reports may be made under the continuous release reporting regulation. Discussions should be initiated with the EPA Region, SERC, and LEPC about such reporting.

14. Is migration of contaminants into groundwater or movement of a contaminated groundwater plume subject to CERCLA \$103 or EPCRA §304 reporting requirements?

NO. Generally, such migration or movement would not represent a release from a facility into the environment. Once the release has occurred (and presumably reported) and the soil or ground water is contaminated, migration of the pollutants through the environment would not be a reportable event. That is, a released quantity moving from one environmental medium to another is not considered a separate release event.

15. What is the relationship between Threshold Planning Quantities (TPQs) and release reporting?

There is no direct relationship between TPQs and the RQs used to trigger release reporting, although $R Q s$ are generally less than or equal to TPQs. EPA has assigned both an RQ and a TPQ to each EHS. If a facility has present onsite an EHS in a quantity equal to or in excess of the TPQ, that facility is subject to the EPCRA $\S 303$ planning requirements (40 CFR 355.30). RQs, in contrast, are used to trigger reports of releases of EHSs and hazardous substances. 
APPENDIX A

\section{LIST OF HAZARDOUS AIR POLLUTANTS}




\section{CLEAN AIR ACT HAZARDOUS AIR POLLUTANTS ADDED TO THE LIST OF CERCLA HAZARDOUS SLBSTANCES}

\section{$60) 355$ \\ 92671 \\ 90040 \\ 71432 \\ 92524 \\ 100940 \\ 150627 \\ 105602 \\ $+63581$ \\ 120809 \\ 133904 \\ 79118 \\ 532274 \\ 126998 \\ 108394 \\ 95487 \\ 1064+45 \\ $35+7044$ \\ 3.34883 \\ $1.526+9$ \\ $111+22$ \\ 916607 \\ $6+675$ \\ 121697 \\ 68122 \\ 106887 \\ 107211 \\ 822060 \\ 680319 \\ $1105+3$ \\ 123319 \\ 16341044 \\ 101779 \\ 92933 \\ 59892 \\ 106503 \\ 57578 \\ 123386 \\ 114261 \\ 961993}

C.AS Number

\section{Chemical Vame}

Acetamide

4-Aminobiphenyl

o-Anisidine

Benzene (including benzene from gasoline)

Biphenyl

1.3.-Butadiene

Calcium cyanamide

Caprolactam

Carbonyl sultide

Catecinui

Chloramben

Chloracetic acid

2-Chloroacetophenone

Chloroprene

m-Cresol

o-Cresol

p-Cresol

DDE

Diazumethane

Dibenzoturans

Diechanolamine

$\therefore$... -Diethylaniline

Diethyl sulfate

$\therefore$..V-Dimethylaniline

Dimethyl formamide

1.2-Epoxybutane

Erhylene glycol

Hexamethylene-1.6-diisocyanate

Hexamethylphosphoramide

Hexane

Hyiroquinone

Methyl tert butyl echer

4.t'-.Mrethylenedianiline

+-.itrubiphenyl

$\therefore$-Vitrosomorpholine

p-Phenylenediamine

beta-Propiolactone

Propionaldehyde

Propoxur (Baygon)

Styrene oxide

* Each of these substances has a statutory reportable quantity of one pound until adjusted by
regulation. 


\section{C.AS : Vumber}

7550450

1582098

$5+108+1$

59.3612

108383

$95+76$

106423

--

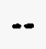

$-$

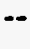

\section{Chemical Vame}

Titanium tetrachloride

Tritluralin

2.2.7-Trimethylpentane

Vinyl bromide

m-Xulene

o-Yylene

p-Xylene

Cobalt Compounds

Glycol ethers ${ }^{1}$

Vianganese Cumpounds

Fine mineral tibers ${ }^{2}$

Polycylic Organic .Matter

1 Includes mono- and di-ethers of ethylene glycol. diethylene glvcol. and triethylene glycol $\mathrm{R}-(\mathrm{OCH} 2 \mathrm{CH} 2)_{\mathrm{n}}-\mathrm{OR}$ where

$$
\mathrm{n}=1.2 \text { or } 3
$$

$R=$ alkwl or aril groups

$R^{\prime}=R . H$. or groups which. when removed. yield glycol ethers with the structure:

$\mathrm{R}-(\mathrm{OCH}=\mathrm{CH})_{n}-\mathrm{OH}$. Polymers are excluded trom the glycol caregory.

2 Includes mireral tiber emissions from tacilities manutacturing or processing glass. rock. or slag tïoers (or other mineral derived tïoers) of average diameter 1 micrometer or less.

3 Includes organic compounds with more than one benzene ring. and which have a boiling point greater than or equal to $100 \mathrm{C}$. 
APPENDIX B

\section{EPCRA 304 WRITTEN FOLLOWUP FORM}

Reprinted with permission from Right-toKnow Planning Guide, pp. 541:4003-4004.

Copyright 1991 by the Bureau of National Affairs, Inc. (800-372-1033) 


\section{EMERGENCY RELEASE FOLLOWUP NOTICE REPORTING FORM (SECTION 304)}

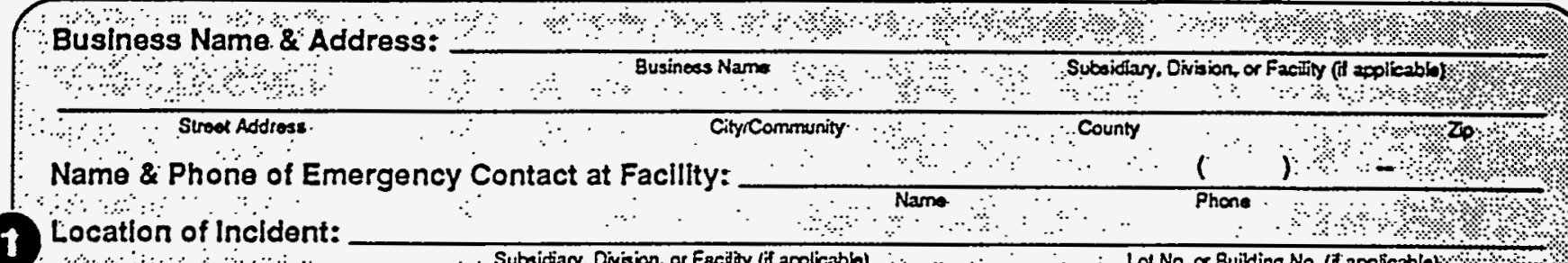

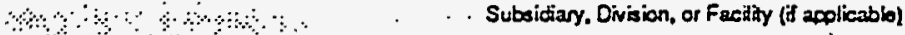

Citycommenity

+a $\because \cdots$

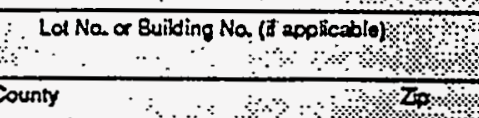

क. Surot Addross.

Date of incldent:

Orqanizations Notifled

Date \& Time of Notiflcation

D National Response Center

(on:

State Emergency Response Commission : Yon

Local Emergency Planning Committee

(an

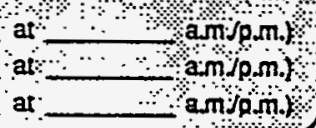

Chemical Name (or Trade Name) \& CAS Number:

Is the Chemical on the Extremely Hazardous Substances (302) List? $\square$ Yes Is the Chemical:Release Reportable Under CERCLA 103(a)? $\square$ Yes $\square$ : No Physlcal:State Stored: ' $\square$ Solld : $\square$ Uquid $\square$ Gas

\section{IIme of Release \\ Duration of Release}

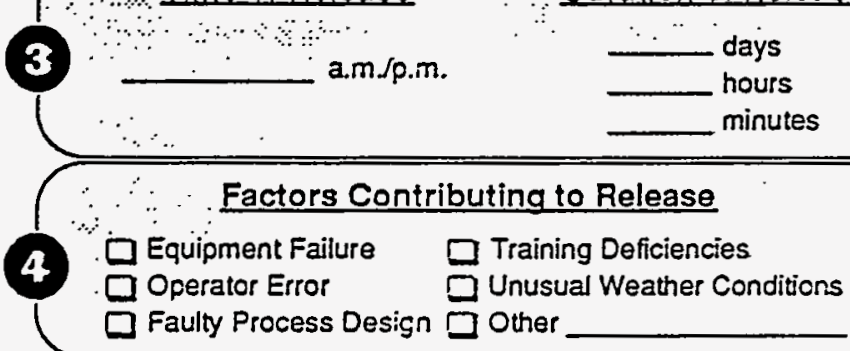

\section{Physical State Released}

$\square$ Solid
$\square$ Uquid
$\square$ Gas

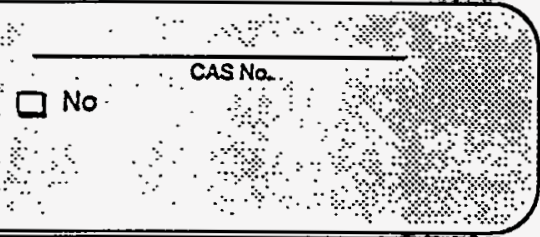

Qeased Quantity Releasod. 


\section{Instructions for Completing this Form}

Block 1 - Enter the name of the business, name and telephone number of the facility contact who can provide detailed information concerning the accidental release. Include the street address, city, county, and zip code where the accident cccurred. Indicate the date of the incident. Place a check mark beside the organization(s) notified and indicate the time verbal notification was made.

Block 2 - Provide information about the chemical that was released. Include the chemical or trade name and the Chemical Abstract Service (CAS) number. Indicate whether the chemical is listed as an EPCRA Section 302 extremely hazardous substance. Check if the chemical also is reportable under Superfund. Mark the category that applies to the chemical's physical state during storage.

Block 3 - Indicate the time the release first started and its duration. Note the chemical's physical state when it was released. Provide the best available information on how much of the substance was released into the environment.

Block 4 - Mark all categories that may have contributed to the accident. Use the comments section or attach a separate sheet, if necessary.

Block 5 - Mark all categories that show which agencies were notified of the release. Use the comments section or attach a separate sheet, if necessary.

Block 6 - Check all actions taken to contain the release. Include actions taken by the facility and by emergency responders (firefighters, police, etc.)

Block 7 - List known or anticipated acute or chronic heaith risks associated with the release. Describe the likelihood of disease or death resulting from human exposure to a potential environmental hazard. List the number of injuries and hospitalizations that resulted from the release. Give any information available about concentrations or levels of exposure.

Block 8 - What are the consequences if people are exposed to the released substance? Indude information on the type of medical attention required for individuals exposed to the chemical released. Provide information on how long the short-term health effects (those that may show up within a few weeks of the incident) will continue to be felt. Describe any long-term concerns. Indicate when and how this information was made available to those exposed and to medical personnel.

Block 9 - List any additional pertinent information, including any potential danger to fish or wildlife, as well as the media into which the chemical was released.

Print or type the name of the reporting facility representative. Include the signature of the reporter and the date the report was submitted. Mail the completed form to the state emergency response commission in the state where the accident occurred and copies to all local emergency planning committees whose jurisdictions may be at risk from the release (See Right-To-Know Planning Guide p. 591:1001)

\section{Resources}

Information on toxicological potency and exposure are needed to perform risk assessments. Some resources listed below may help determine the extent of the health risk resulting from a toxic release.

State Emengency Response Commissions. Each state is required to establish a commission that serves as the link between local and federal emergency response teams. The SERC supervises the local emergency planning committee's actions by coordinating chemical information received from industry and EPA and assists understanding and communicating chemical risks.

Local Emergency Planning Committees. These local groups include representatives from many organizations including elected officials, police and fire departments, health, environment, and transportation agencies. LEPCs may have meteorological, topological, hydrological, and demographic information.

State/Local Poison Control Centers. Toxicologists at poison control centers can discuss the acute and chronic health effects from exposure to hazardous chemicals and describe preventive actions and remedial measures that should be taken to minimize health problems.

American Chemical Society (ACS). This industry organization has nearly 200 local chapters across the United States. Its members are chemists and chemical engineers who can help interpret technical data. (202) 872-4600.

Agency for Toxic Substances and Disease Registry (ATSOR). Personnel from this agency, which is a component of the Centers for Disease Control, can discuss toxic subsiance use and associated adverse health effects. Call your EPA regional offico (See Right-To-Know Planning Guide p. 591:2231).

Census Bureau. Data may be reviewed to determine the size, distribution, and demographic characteristics of a geographically defined population.

Comments
(Please use this space for additional comments or information.)

